\title{
Kajian Hadis tentang Halal, Haram, dan Syubhat
}

\author{
Amir Mahmud \\ amirhoney1212.am@gmail.com \\ Univesitas Yudharta Pasuruan, Jawa Timur
}

\begin{abstract}
This article analyzes the hadiths concerning halal, haram, and syubhat and the attitude of the prophet on syubhat. The method applied in this article includes three aspects: 1 . Explaining of the quantity and quality of the hadith in terms of sanad and matan namely explanation of the status of hadith. 2. Describing the meaning of hadith 3 . Uncovering laws and wisdom contained in them. The method of analysis based on takhrij, criticism of sanad and matan, as well as explanation of hadith meaning is used to explore the quality of hadits. This article found that the Prophet Muhammad always warned his people to be aware on halal, haram, and syubhat condition. The Prophet (peace be upon him) demonstrates his thoughtful attitude towards the syubhat by avoiding it.
\end{abstract}

Keywords: Halal, Haram, Syubhat

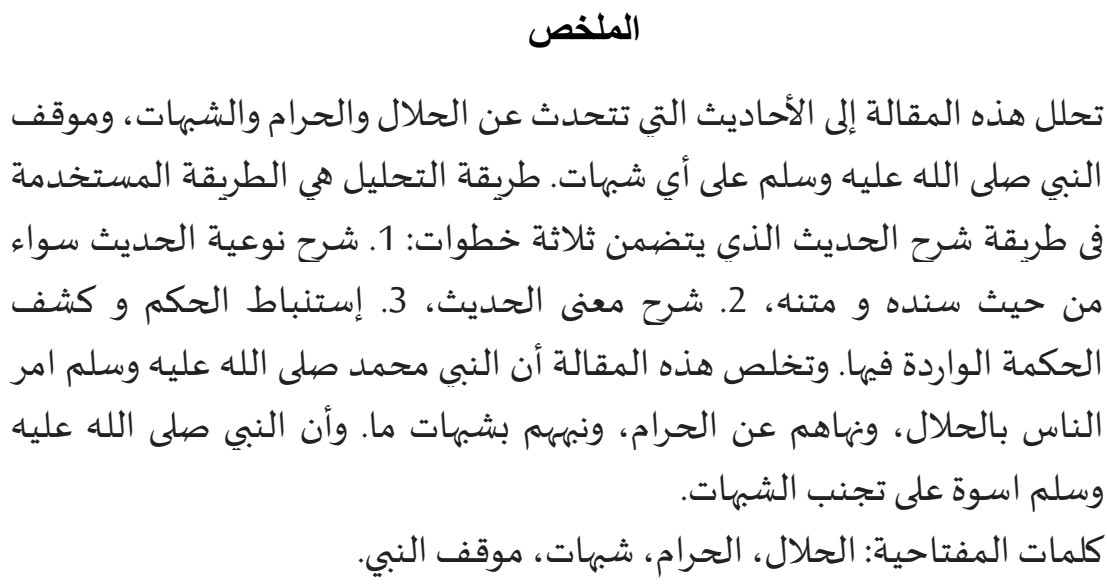

Abstrak

Artikel ini menganalisis hadits tentang halal, haram, dan syubhat. Masalah yang dibahas adalah makna hadits yang berbicara tentang 
halal, haram, dan syubhat, dan bagaimana sikap Nabi terhadap halhal yang syubhat. Metode yang digunakan adalah metode syarah hadis yang meliputi tiga aspek: 1. Menjelaskan kuantitas dan kualitas hadis baik dalam hal sanad dan matan. Dengan kata lain, jelaskan stat us hadis. 2. Jelaskan arti hadis 3. Mengungkap hukum dan hikmat yang terkandung di dalamnya. Metode analisisnya adalah metode analisis dalam hadits yang umumnya terdiri dari takhrij, kritik terhadap sanad dan matan, dan penjelasan tentang makna hadits. Artikel ini menemukan bahwa Nabi Muhammad SAW selalu memberikan kesadaran kepada masyarakat tentang halal, haram, dan syubhat. Nabi (saw) mencontohkan sikap hati-hati terhadap syubhat dengan memilih menjauhinya.

Kata kunci: Halal, Haram, Syubhat, sikap Nabi

\section{A. Pendahuluan}

Umat Islam meyakini bahwa agama yang diakui oleh Allah swt adalah Islam yang secara bahasa berarti keselamatan. Realisasi makna keislaman menghendaki agama ini memiliki petunjuk atau pedoman bagi seluruh sisi kehidupan manusia.

Pemaknaan Islam sebagai agama yang membawa ajaran, pedoman atau petunjuk kepada umat manusia secara umum dan kepada umat Islam secara khusus mengandung harapan bahwa manusia, terutama yang beragama Islam akan memiliki kehidupan yang damai, tentram, dan selamat di dunia serta di akhirat. Pedoman itu diharapkan menjadi acuan manusia dalam menjalani kehidupannya di dunia yang dinamis sekaligus kompleks.

Kompleksitas lingkungan hidup menjadi tantangan tersendiri terhadap manusia dalam mengupayakan keselamatannya. Realitas ini diisyaratkan oleh Allah swt dalam al-Qur'an bahwa kehidupan dunia itu adalah cobaan itu sendiri, bahkan eksistensi manusia itu sendiri merupakan ujian bagi dirinya. Hal itu dipahami dari penegasan Allah swt bahwa manusia diberi indera pengukur dan pemilih beserta pilihan-pilihan yang akan ditemuinya dalam realitas kehidupannya. ${ }^{1}$ Pilihan-pilihan itu kemudian dimintai pertanggungjawaban kelak pada hari perhitungan atau hari akhirat. $^{2}$

Kehidupan manusia di dunia memang dinamis, tetapi Islam merupakan agama yang memiliki petunjuk dan regulasi yang komplet, mencakup semua aspek kehidupan pemeluknya. Aturan Islam yang dimaksud merupakan manifestasi dari sumber ajarannya, yaitu Al-Qur'an dan sunah Rasul. AlQuran berfungsi sebagai petunjuk, bukan saja kepada orang Islam (hudan li almuttaqīn), tetapi juga bagi manusia seluruhnya (hudan li al-nās). Sunnah Rasul berfungsi sebagai penjelasan al-Quran (tibyān), sehingga sunnah merupakan bimbingan praktis dan operasional dari nilai-nilai al-Quran. Dengan demikian, dalam Islam terdapat petunjuk atau pedoman hidup (guidance) dan tunt unan praktis dalam menjalani kehidupan manusia (way of life $)^{3}$ 
Harapan atau idealitas seseorang di dunia telah diberikan pedoman dan tuntunannya oleh agama Islam, yiatu al-Qur'an dan Hadis. Dua kitab pedoman tersebut merupakan pusaka yang harus dipegang teguh dalam keyakinan dan dipedomani sepanjang hidup.

Hadis atau Sunnah Nabi saw merupakan tuntunan praktis al-Qur'an, sekaligus menjadi bentuk perhatian dan kasih sayang Nabi saw kepada umatnya untuk selalu berada dalam lintasan yang lurus. Nabi Muhammad saw. memberikan rincian-rincian petunjuk agar umatnya mudah memahaminya dan mengamalkannya demi tercapainya harapan hiup, yaitu mendapatkan keselamatan hidup di duni dan di akhirat.

Salah satu aturan dan tuntunan yang penting dalam kehidupan umat manusia dan terutama umat Islam adalah prihal kehalalan dan keharaman sesuatu, baik berupa sikap, maupun berupa makanan/minuman. Kedua hal itu menjadi urgen diketahui karena di antara keduanya terdapat hal yang disebut syubhat (keragu-raguan atau ketidakjelasan antara halal dan haram) ${ }^{4}$. Nabi Muhammad saw menghendaki agar umatnya menaruh perhatian pada hal-hal yang halal dan memperhatikan segala hal yang haram untuk mengetahui hal-hal di antara halal dan haram (subhat).

Persoalan halal, haram, dan syubhat memiliki andil besar dalam menentukan keselamatan hidup setiap orang. Dengan demikian, petunjuk al-Qur'an dan tuntunan Nabi saw. menjadi penting untuk diketahui.

Fokus kajian ini adalah petunjuk Nabi Muhammad saw perihal halal, haram, dan syubhat, dengan pokok pembahasan bagaimana petunjuk Nabi Muhammad saw terhadap prihal halal dan haram, serta prihal yang meragukan antara halal dan haram atau syubhat.

Hadis yang menjadi acuan adalah sabda Nabi saw:

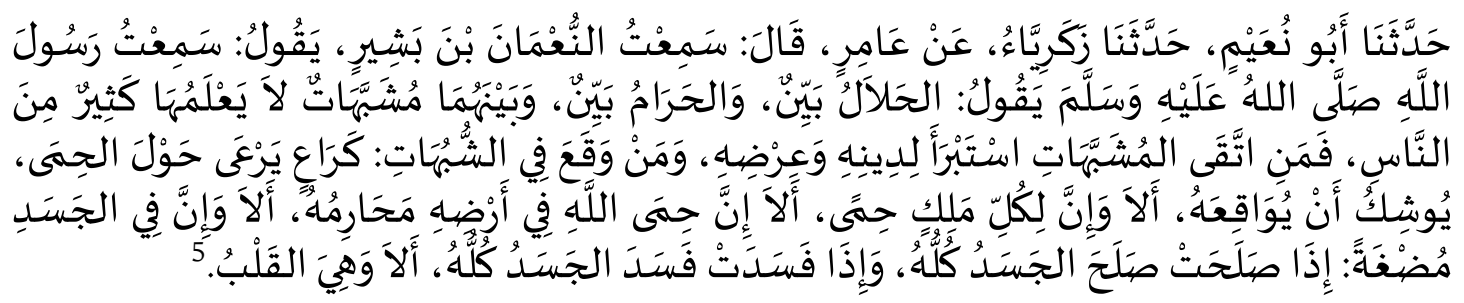

Artinya:

Telah menceritakan kepada kami $\mathrm{Abū} \mathrm{Nu}$ 'aim, telah menceritakan kepada kami Zakariyā' dari 'Āmir yang berkata saya mendengar al-Nu'mān bin Basyï berkata saya mendengar Rasulullah saw. bersabda; yang halal sudah jelas dan yang haram juga sudah jelas, tetapi di antara keduanya ada hal-hal yang syubhat (samar) yang tidak diketahui oleh banyak manusia. Barangsiapa menjauhi syubhat maka ia telah memelihara agama dan kehormatannya, barangsiapa mendekati syubhat maka ia seperti penggembala yang mengembalakan ternaknya di pinggir jurang yang berpotensi jatuh ke dalamnya. Ketahuilah bahwa setiap raja memiliki batasan, dan ketahuilah bahwa batasan larangan Allah swt. di bumi-Nya adalah apapun yang diharamkan-Nya. Ketahuilah pada setiap tubuh ada segumpal darah (mudghah), 
apabila ia baik maka baiklah keseluruhan tubuh, apabila rusak maka rusaklah keseluruhan tubuh tersebut. Ketahuilah, ia adalah al-qalb.

\section{B. Metode penelitian}

\section{Takhrij Hadis}

Untuk mendapatkan keterangan yang komprehensif dari hadis di atas, maka pengungkapan redaksi hadis dari beberapa kitab sumber akan dikutip dalam tulisan ini melalui kamus hadis Miftāh Kunūz al-Sunnah ${ }^{6}$ sebagai berikut:

1. Saḥịh al-Bukhārī ditemukan di dua tempat

a. Dalam kitāb al-İmān ${ }^{7}$

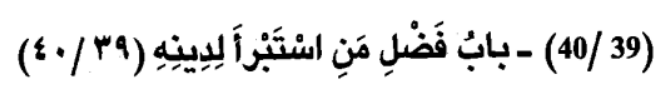

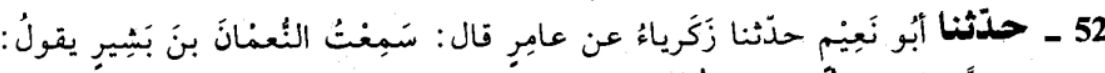

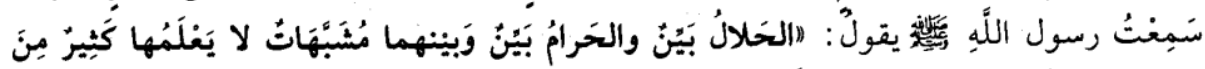

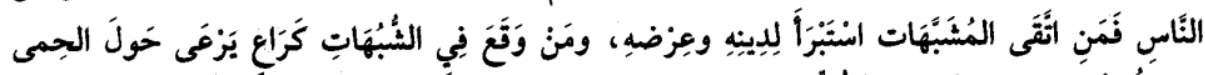

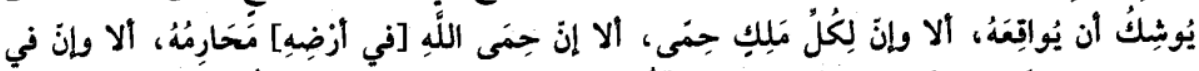

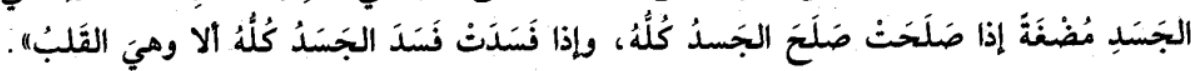

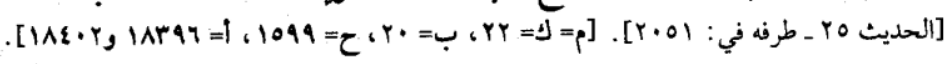

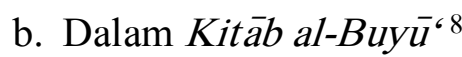

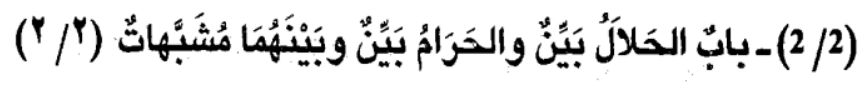

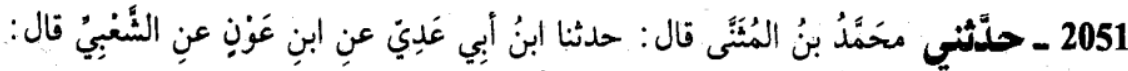

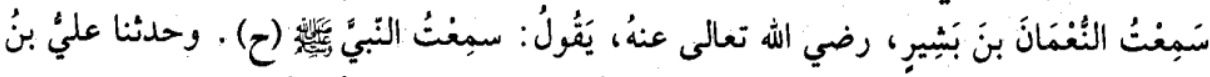

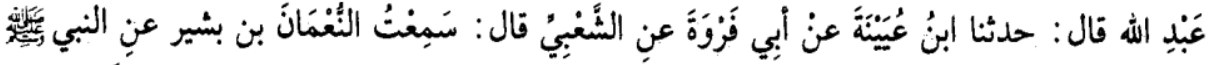

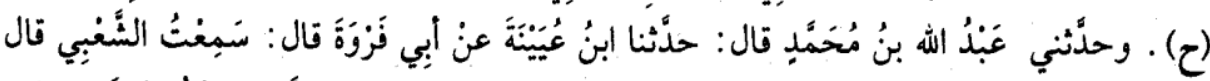

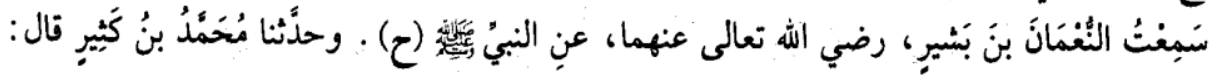

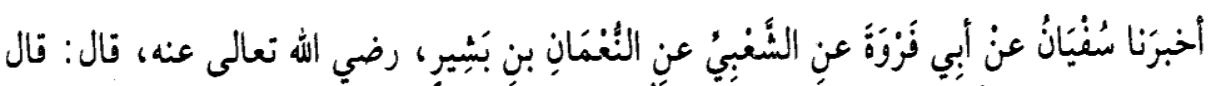

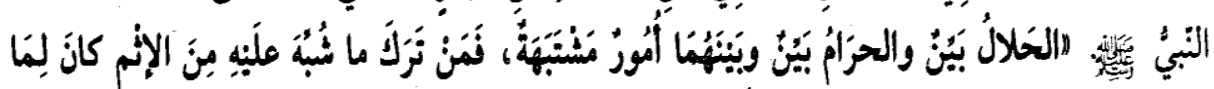

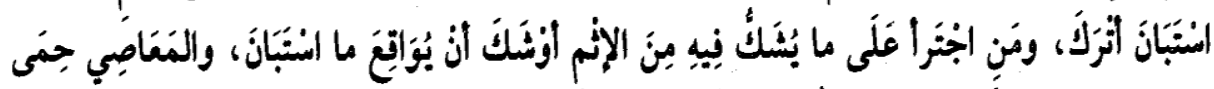

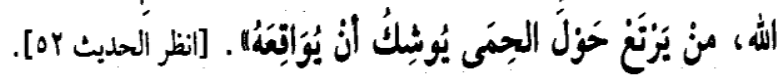

2. Sahịị Muslim dalam Kitāb al-Musāqā ${ }^{9}$ 


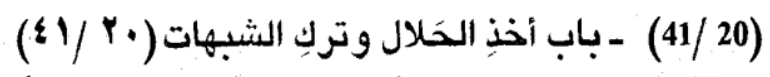

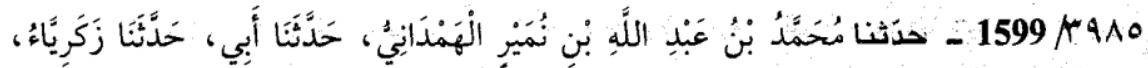

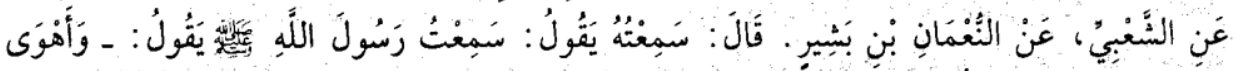

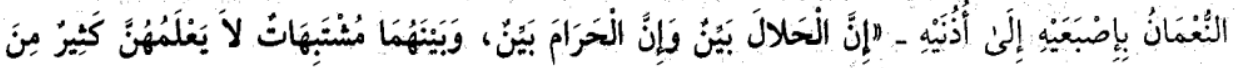

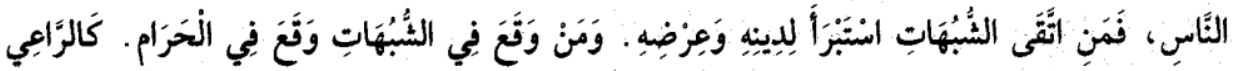

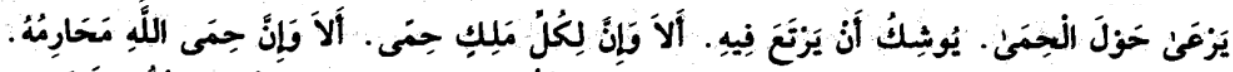

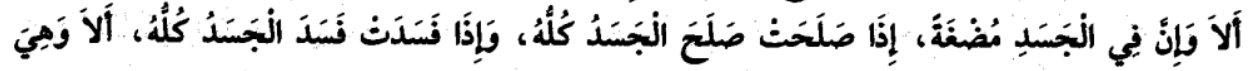

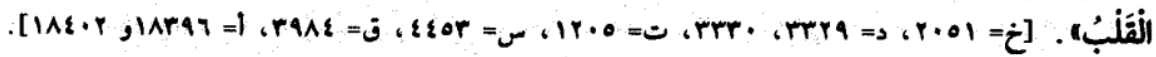

3. Sunan Abū Dāwud dalam Kitāb al-Buy" $\bar{u}^{\circ 10}$

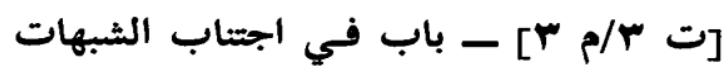

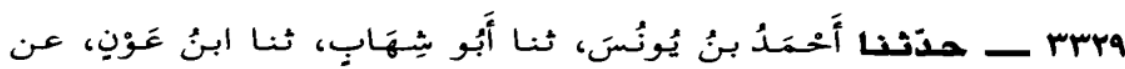

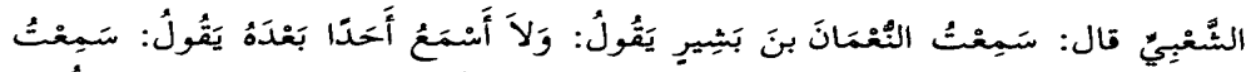

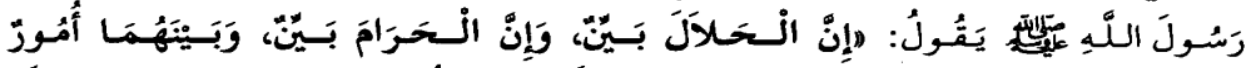

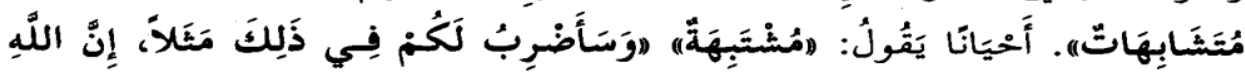

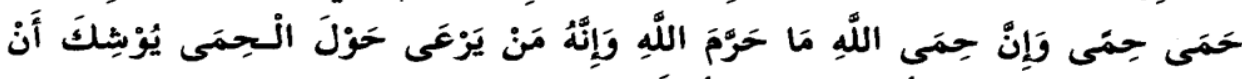

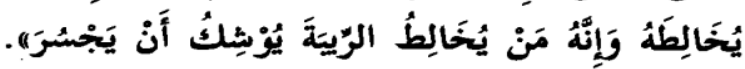

\section{Sunan al-Tirmiḍi Kitāb al-Buyū' 11}

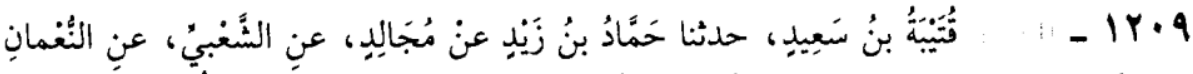

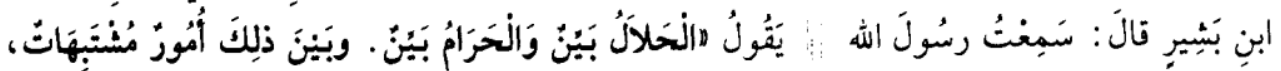

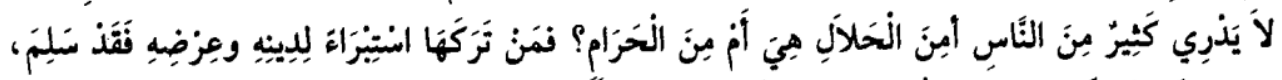

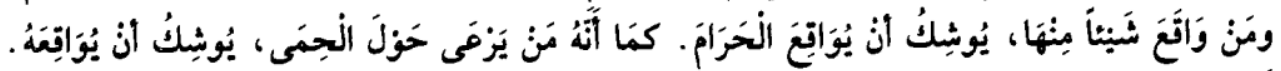

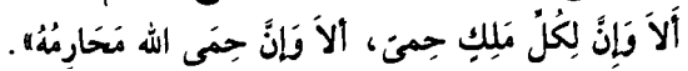

5. Sunan al-Nasā'i ditemukan di dua tempat

\section{a. Kitāb al-Buyü'12}

$$
\text { (2/2) - باب اجتناب الشبهات في الكسب }
$$

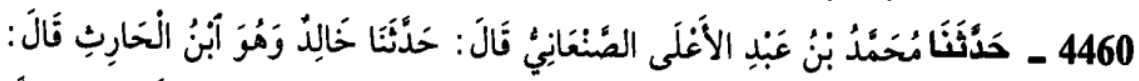

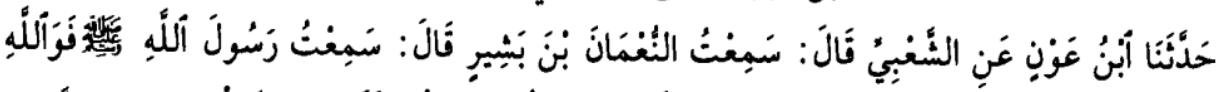

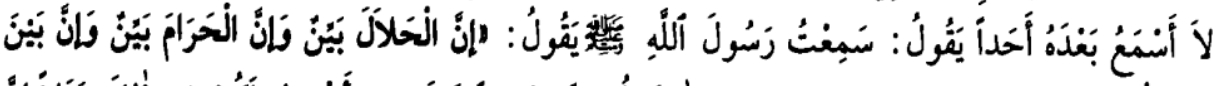

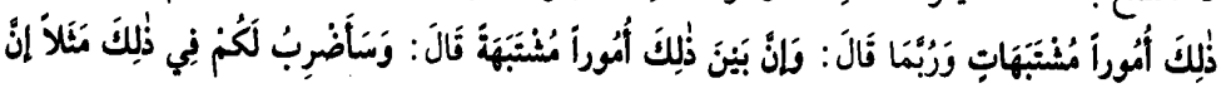




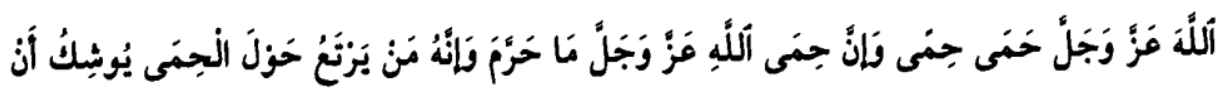

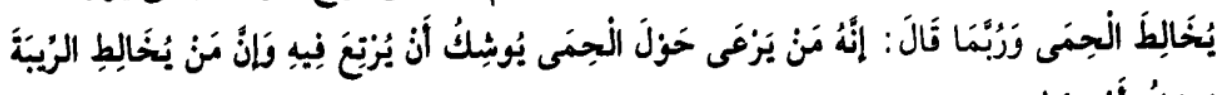

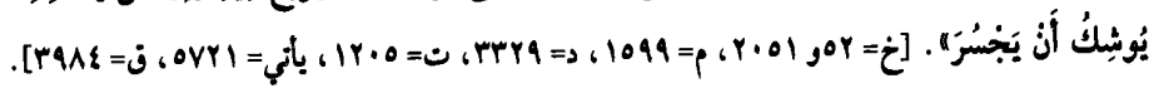

b. Kitāb al-Asyribah ${ }^{13}$

$$
\text { (50/50) - باب الحث على ترك الشبهات }
$$

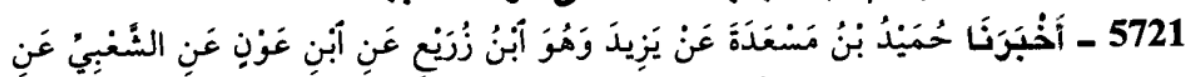

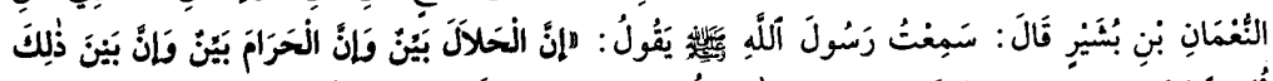

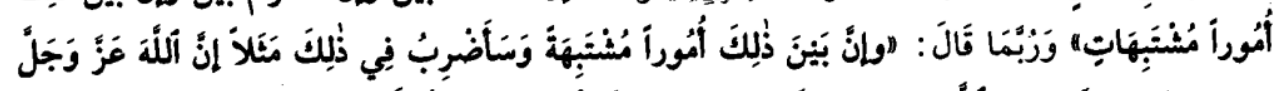

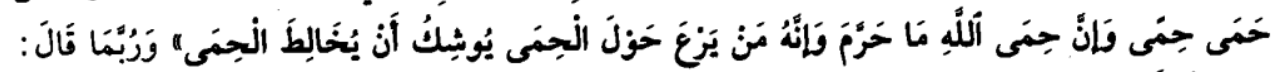

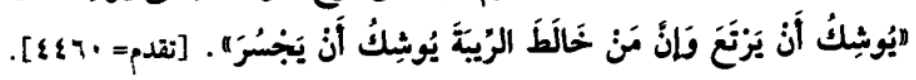

6. Sunan Ibnu Mājah dalam Kitāb al-Fitn ${ }^{14}$

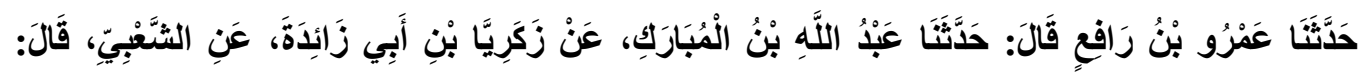

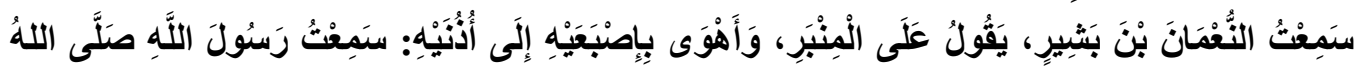

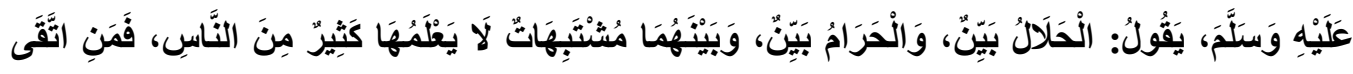

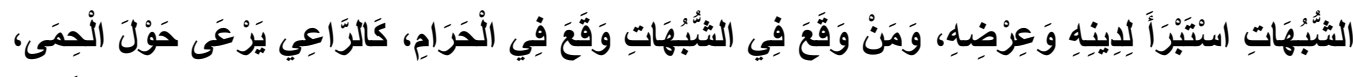

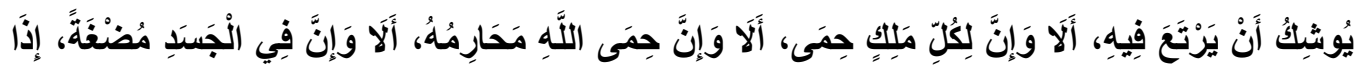

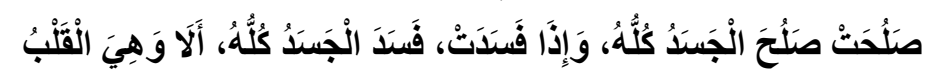

7. Sunan al- Dārimī dalam Kitāb al-Buy $\bar{u}^{\cdot 15}$

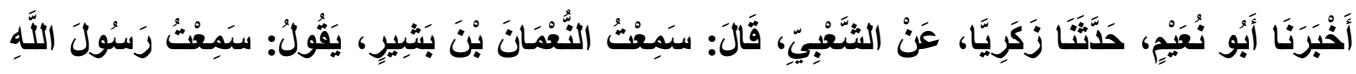

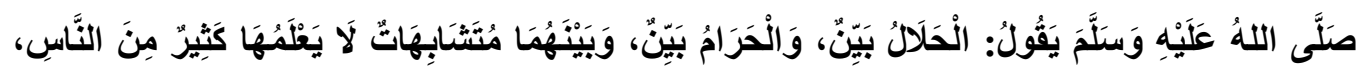

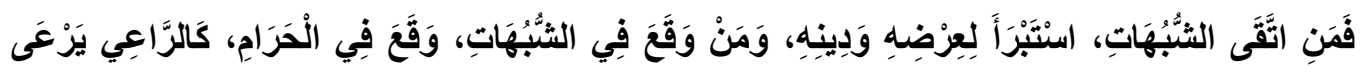

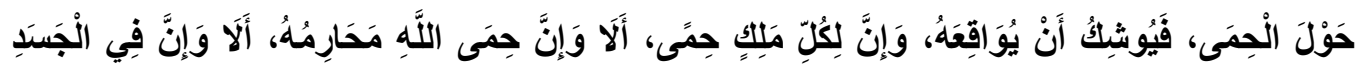

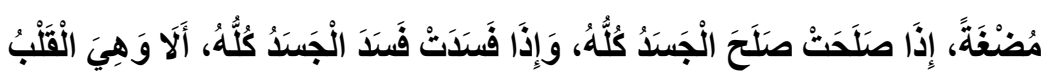

\section{Musnad Ahmad bin Hanbal}

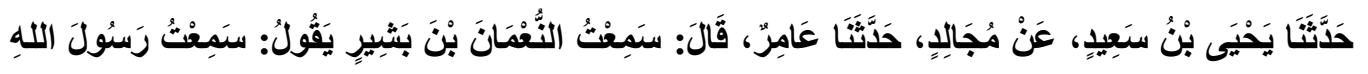

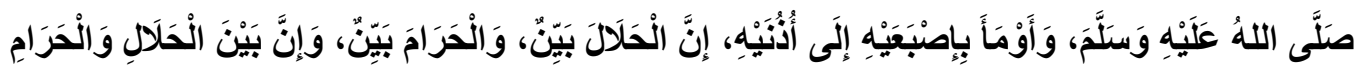

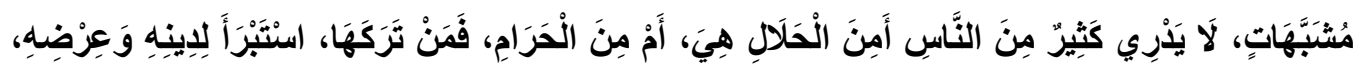




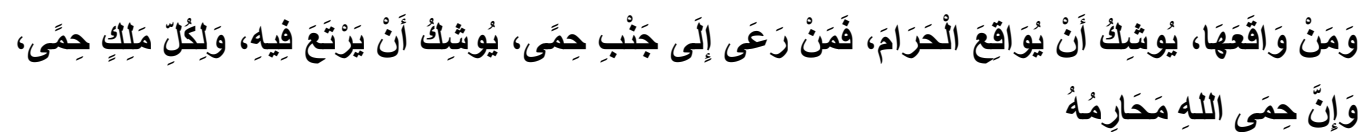

\section{Variasi Riwayat Hadis}

Hasil penelusuran melalui kamus hadis karya A.J. Weinsink di atas, bisa diambil kesimpulan bahwa hadis ini adalah Riwāyah bi al-Ma'nā. Hal tersebut terlihat dari redaksi hadis yang tidak sama antara satu hadis dengan hadis lain.

Dari sekian redaksi hadis, teks hadis yang mempunyai kesamaan dalam

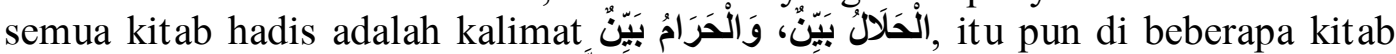
kitab masih menambahkan kata إنَّ sebelum kalimat tersebut. Kitab hadis yang meletakkan kata إنَّ adalah kitab Musnad Ahmad bin Hanbal, Sunan al-Nasä'i, Sunan Abī Däwud dan Sahịh Muslim.

Selanjutnya setelah redaksi tersebut, teks hadis mempunyai banyak variasi. Penekanan sabda Nabi saw. pada bagian selanjutnya yang menyatakan tentang syubhat terangkai dengan redaksi yang variatif. Namun demikian, ragam rangkaian redaksi tentang syubhat dalam hadis ini tidak keluar dari makna tentang syubhat itu sendiri. Artinya, tidak satu pun redaksi hadis dari delapan kitab hadis di atas mempunyai makna ambigu.

Sedangkan potongan redaksi selanjutnya setelah menjelaskan tentang syubhat, teks hadis ini lebih banyak lagi ragamnya. Beberapa redaksi menyatakan bahwa perkara syubhat lebih menjerumuskan seseorang pada hal yang haram secara jelas, redaksi yang lain menggambarkan dengan sebuah analogi, bahkan ada juga teks hadis yang menyambungkan kepada dampak ke-halal-an, ke-haram-an dan ke-syubhat-an terhadap manusia. Variasi hadis yang begitu beragam ini akan dijelaskan pemaknaannya pada bagian selanjutnya secara mendalam.

\section{Korelasi Periwayat Sahabat dan Hadis}

Hadis tentang halal, haram, dan syubhat dalam delapan kitab hadis ini, periwayatannya dari kalangan sahabat hanya diriwayatkan oleh satu orang saja, yakni al-Nu'mān bin Basyïr. Nama lengkapnya adalah al-Nu'mān bin Basyïr ibn

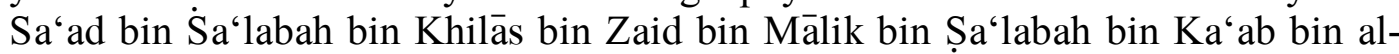
Khazraj al-Anshāri. Ia adalah orang pertama lahir dari golongan Anshor setelah kepindahan Nabi saw. ke Madinah. Ibunya bernama 'Amroh bint Rawāhahah, alNu'mān dan Bapaknya merupakah sahabat Rasulullah saw. ketika Nabi saw. wafat, ia berusia delapan tahun tujuh bulan. ${ }^{16}$ Dengan usia di bawah sepuluh tahun, al-Nu'mān tergolong pada sahabat kecil.

Al-Nu'mān pernah menjabat sebagai Gubernur Kufah pada masa pemerintahan $\mathrm{Mu}^{\circ}$ āwiyah, ia meninggal di kota Hims ${ }^{17}$ di usia 60 tahun. ${ }^{18}$ Jabatan gubernur, menunjukkan bahwa ia termasuk sahabat yang mendapatkan kepercayaan $\mathrm{Mu}^{\prime} \bar{a}$ wiyah serta termasuk kelompok sahabat yang mempunyai pengaruh di kalangannya.

Sebagai golongan sahabat kecil, ia tidak hanya meriwayatkan hadis yang didengarnya langsung dari Rasulullah saw. tetapi ia juga meriwayatkan hadis dari Khālid bin 'Abd Allāh bin Rawāhah, 'Umar dan 'Aisyah. ${ }^{19}$ Generasi berikutnya

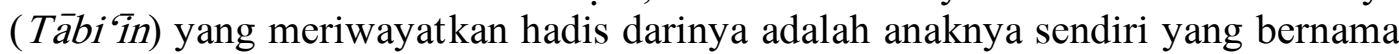


Muhammad, Basyīr, Ḥumaid bin 'Abd al-Raḥmān, al-Sya'bì ('Āmir al-Sya‘bī), Khaỉsamah, Simāk bin Harb, Sālim bin Abī al-Ja'd, 'Abd al-Malik bin 'Umair, Abū Isḥāq al-Sabī'iy, Hạīib bin Sālim dan Yasī' al-Haḍramiy. ${ }^{20}$ Dalam referensi kitab lain, bisa jadi orang-orang yang meriwayatkan hadis darinya lebih banyak lagi.

Selain hadis tentang halal, haram, dan syubhat ini, al-Nu'mān banyak meriwayatkan hadis lain. Periwayatan hadis oleh al-Nu'mān sebagian disebutkan dalam kitab Ma'rifah al-Sahābah, menunjukkan bahwa ia beserta ayahnya adalah kelompok sahabat yang aktif dalam mendapatkan petunjuk Nabi Muhammad saw.

Bukti keaktifan al-Nu'mān mendekati Nabi saw. adalah adanya riwayat yang menceritakan bahwa ia seringkali diajak oleh ayahnya pergi menemui Nabi saw. Bahkan, ibunya pun tergolong wanita yang seringkali ingin memutuskan sesuatu meminta pertimbangan kepada Rasulullah saw. Riwayat riwayat ini memperkuat biografi seorang al-Nu'mān sebagai seorang yang dekat dengan Nabi saw. dan layak meriwayatkan sebuah hadis karena kedekatannya.

Meskipun ia salah satu sahabat yang dekat dengan Nabi saw. dalam meriwayatkan hadis yang dihimpun dalam delapan kitab hadis ini, redaksi hadis antara satu kitab dengan kitab lainnya tidak beredaksi dengan teks yang sama (riwāyah bi al-ma'nā). Dalam hal ini susah untuk menelusuri pada level manakah perubahan redaksi hadis terjadi.

Namun, jika melihat murid atau orang yang meriwayatkan darinya hanyalah

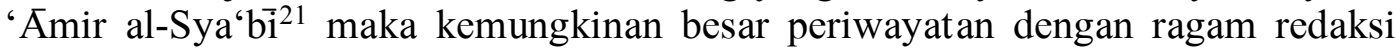
hadis terjadi setelah al-Sya'bì. Meskipun demikian, ragam redaksi hadis dari al$\mathrm{Nu}^{\prime}$ 'mān ini tidak menggugurkan nilai kesahihannya karena dari sekian ragam teks tersebut adalah maknanya sama.

\section{B. Pemaknaan Hadis dan Analisis Teoritis}

Sebelum uraian secara panjang lebar tentang hadis halal, haram, dan syubhat ini lebih jauh, maka pemaknaan perkata secara leksikal dipandang penting untuk dicantumkan terlebih dahulu. Kata-kata tertentu akan diuraikan pemaknaannya secara kamus.

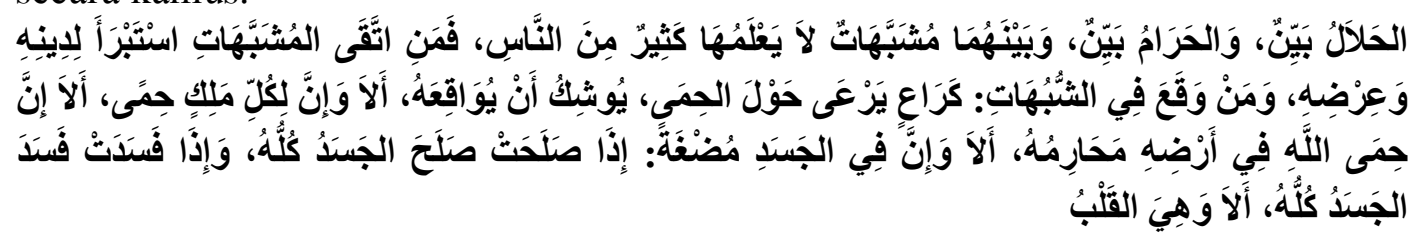

\section{Arti Mufradāt}

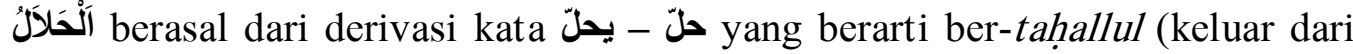
ihrām), halal, berhenti atau tinggal di, tinggal, berdiam di, menempatkan, menimpa, terjadi, tetap, pasti, melepaskan, menguraikan ${ }^{22}$ dan lain sebagainya. Banyak cabang arti dari kata ini, kecenderungan arti kata حلّ - يحلّ tergantung pada konteks susunan kalimat yang mendampinginya.

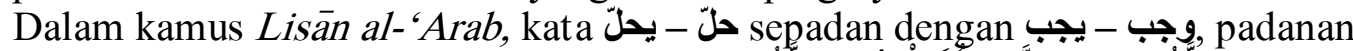

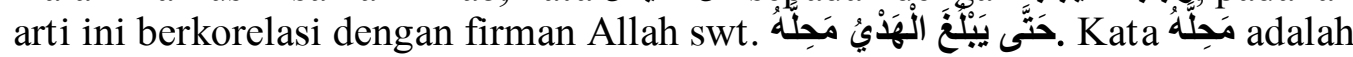
tempat dihalalkan dan atau diwajibkan menyembelih hewan kurban. ${ }^{23}$ Dengan demikian, halal mengandung makna keharusan. 
الحَرَامُ الحَرَامُ

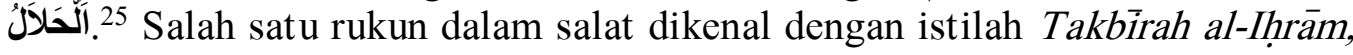
istilah tersebut menunjukkan bahwa takbir merupakan tanda bagi seseorang memasuki salatnya, sehingga ia tidak boleh lagi atau tercegah untuk berucap dan berbuat sesuatu di luar ketentuan yang harus dilakukan di dalam sholat. ${ }^{26}$ Kata haram juga terlihat pada beberapa keterangan tentang Mekkah dan Madinah yang disebut dengan istilah al-Haramain dikarenakan pada dua area tersebut tidak diperbolehkannya melakukan sesuatu, meskipun hal itu diperbolehkan (halal) jika dikerjakan di luar area Mekkah dan Madinah.

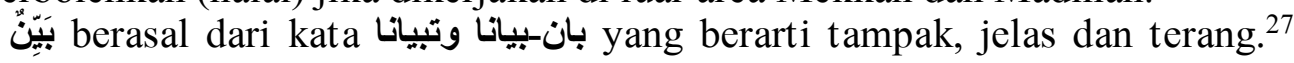
Secara lebih konkrit arti kata tersebut adalah sesuatu yang diperjelas oleh dalildalil atau hal lain. ${ }^{28}$ Kejelasan di sini jika terlihat nyata atau tidak menimbulkan ambiguitas dari dalil-dalil tertentu dalam menyimpulkan makna yang dimaksud.

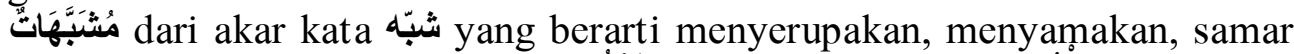

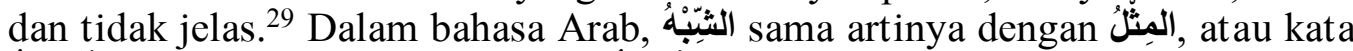
sama juga artinya dengan المُشْنَتِهِاتُ jika warna ia adalah abu-abu.

قَلب yang berarti merubah (bentuk, rupa dan sebagainya), membalikkan, menjadikan dan lain-lain, juga berarti اللب (hati, isi, lubuk hati, jantung, inti), العقل (akal), القوة او الثجاعة (kekuatan, semangat, keberanian), الباطن (sebelah/bagian dalam), الوسط (pusat, bagian tengah, tengahtengah), المحض والخالص (yang murni). ${ }^{31}$ Dalam Lisān al-Arab القنب (لقبط diartikan berpalingnya sesuatu dari tempatnya, ia juga dikatakan sebagai sesuatu yang lemah. ${ }^{32}$ Ketepatan mengartikan القَّبُْ harus melihat konteks kata tersebut diucapkan karena banyaknya kemungkinan arti yang dikandungan.

\section{Ruang Lingkup Halal, Haram dan Syubhat}

Halal, haram, dan syubhat dalam arti etimologis seperti disebitkan di atas, telah memberikan penjelasan tentang makna kata tersebut. Kejelasan tentang ke-halal-an dan ke-haram-an dalam Islam didapati karena adanya dalil yang mutlak ( qat $\left.^{\prime} \overline{1}\right)$. Sedangkan syubhat, adalah sesuatu yang masih samar tentang status ke-halal-an dan ke-haram-annya, atau jika ada sebuah dalil yang menunjukkan status antara keduanya, dalil tersebut masih mengandung dualisme penafsiran.

\section{a. Halal dalam al-Qur'an dan Hadis}

Contoh ragam halal dalam al-Qur'an;

1) Bercinta dengan istri pada malam bulan ramadhan

Terjemahnya:

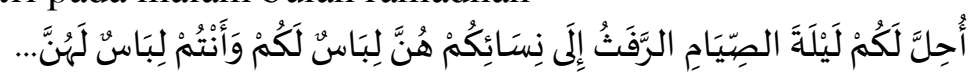

Dihalalkan bagi kamu pada malam hari (bulan) puasa bercampur dengan isteri-isteri kamu; mereka adalah pakaian bagimu, dan kamu (pun) adalah pakaian bagi mereka (al-Baqarah/2: 187). ${ }^{33}$

2) Ke-halal-an makanan dan minuman yang baik

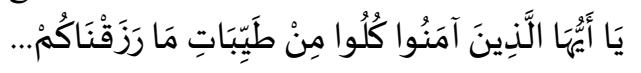


Terjemahnya:

Hai orang-orang yang beriman, makanlah dari rezki yang baik-baik yang Kami anugerahkan kepadamu (al-Baqarah/2: 172). ${ }^{34}$

3) Ke-halal-an semua hewan laut

Terjemahnya:

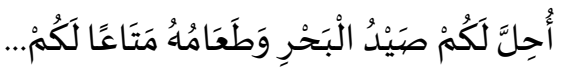

Dihalalkan bagimu binatang buruan laut dan makanannya adalah kesenangan bagi kamu... (al-Mā'idah/5: 96). ${ }^{35}$

4) Ke-halal-an sembelihan ahl al-kitāa

Terjemahnya:

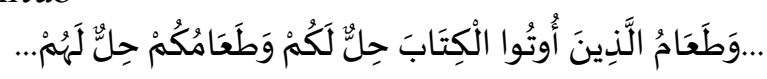

Makanan orang-orang yang diberi al-Kitab (Yahudi dan Nasrani) itu halal bagi kamu, dan makanan kamu halal (pula) bagi mereka (alMà'idah/5: 5). ${ }^{36}$

5) Ke-halal-an jual beli

Terjemahnya:

$$
\text { مَأَحَالَّ اللَّلُهُ الْبَيْعَ.... }
$$

Padahal Allah telah menghalalkan jual beli (al-Baqarah/2: 275). ${ }^{37}$

Contoh ragam halal dalam Hadis;

a. Bercumbu dengan istri dalam keadaan haid selain penetrasi

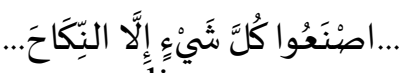

Artinya: Lakukan apa saja (kepada mereka), kecuali menggaulinya.

b. Ke-halal-an dua bangkai (ikan dan belalang)

$$
\text { أُحِلَّتُ لَنَا مَيْتَتَانِ: الْحُوتُ، وَالْجَرَادُ }
$$

Artinya: Dihalalkan bagi kami dua bangkai, yakni ikan dan belalang.

c. Ke-halal-an biawak gurun (

Artinya: Aku tidak memakannya dan aku tidak mengharamkannya

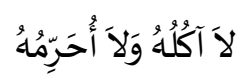

Halal karena tidak dalil yang menyatakan haram;

Artinya: asal segala sesuatu adalah boleh

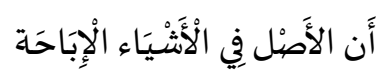

\section{b. Haram dalam al-Qur'an dan Hadis}

Contoh ragam haram dalam al-Qur'an;

1) Ke-haram-an khamr, judi, makanan untuk berhala, mengundi nasib

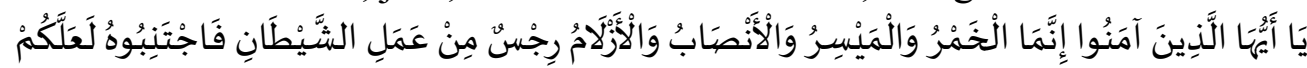

Terjemahnya:

Hai orang-orang yang beriman!, sesungguhnya khamr (dan segala yang memabukkan meskipun sedikit), judi, (berkorban untuk) berhala-berhala, panah-panah (yang digunakan mengundi nasib) adalah kekejian yang termasuk perbuatan setan. Maka, jauhilah ia 
(perbuatan-perbuatan itu) supaya kamu mendapat keberuntungan (al-Mā'idah; 90). ${ }^{38}$

2) Ke-haram-an zina

Terjemahnya:

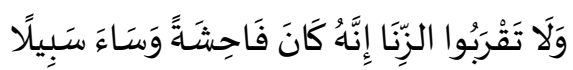

Dan janganlah kamu mendekati zina; sesungguhnya zina itu adalah suatu perbuatan yang keji, dan jalan yang buruk (al-Isrā; 32). ${ }^{39}$

3) Ke-haram-an membunuh

Terjemahnya:

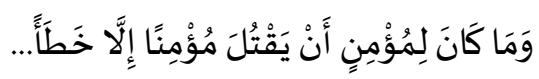

Dan tidak (ada kepatuhan, bahkan tidak ada wujudnya) bagi seorang mukmin membunuh seorang mukmin, kecuali karena tersalah (tidak disengaja)... (al-Nisā'; 92)..$^{40}$

4) Ke-haram-an bangkai, babi dan sembelihan bukan karena Allah swt.

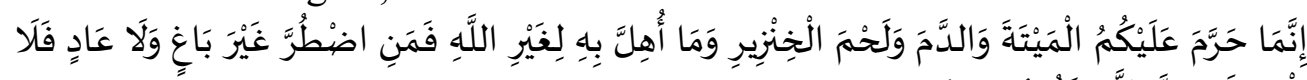

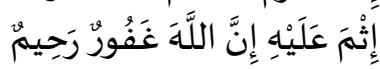

Terjemahnya:

Sesungguhnya (Allah swt.) hanya mengharamkan bagimu bangkai, darah, daging babi, dan apa (binatang) yang (ketika) disembelih (disebut nama) selain Allah. Tetapi, barangsiapa (dalam keadaan) terpaksa (memakannya) sedang dia tidak menginginkan-(nya) dan tidak (pula) melampaui batas, maka tidak ada dosa baginya. Sesungguhnya Allah Maha Pengampun lagi Maha Penyayang (alBaqarah;173). ${ }^{41}$

Contoh ragam haram dalam Hadis;

1) Ke-haram-an mencela

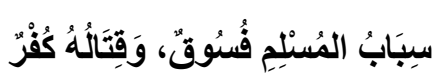

Artinya: Mencela seorang muslim adalah fasiq dan membunuhnya adalah kufur

2) Ke-haram-an mendatangi peramal

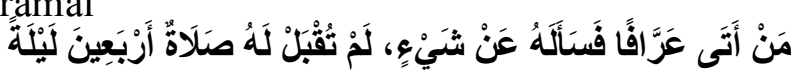

Artinya: Barangsiapa yang mendatangi peramal, lalu bertanya kepadanya tentang sesuatu, maka shalatnya tidak akan diterima selama 40 malam.

3) Ke-haram-an jimat

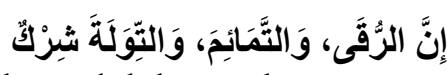

Artinya: Sesungguhnya ruqyah, penangkal, dan pelet, adalah syirik.

4) Ke-haram-an karena ada kaidah sebagai indikator

Artinya: Setiap minuman yang memabukkan, maka itu haram.

$$
\text { كُلُْ شَرَابِ أَسْكَرَ فَهْوَ حَرَامُ }
$$

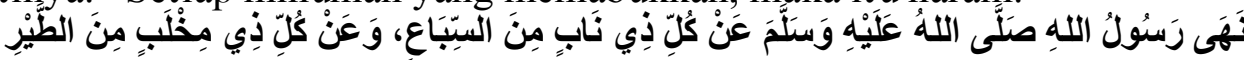

Artinya: Rasulullah Shallallahu 'Alaihi wa Sallam melarang memakan semua binatang buas yang memiliki taring, dan burung yang memiliki cakar. 


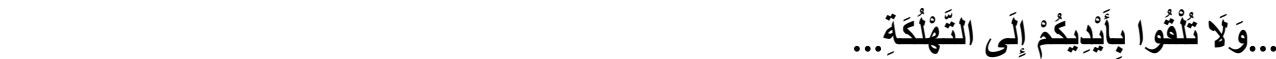

Artinya: ...Dan janganlah kamu menjatuhkan tangan (diri) kamu ke dalam kebinasaan (al-Baqarah; 195). ${ }^{42}$

$$
\text { لَا ضَرَرَ وَلَا ضِرَارَ }
$$

Artinya: Jangan melakukan dharar (kerusakan, kebinasaan), dan jangan menjadi rusak

\section{c. Status syubhat}

Berbeda dengan prihal halal dan haram yang sudah dinyatakan oleh Nabi saw. sebagai sesuatu yang jelas statusnya. Syubhat membutuhkan pemikiran tersendiri untuk menentukan statusnya. Syubhat adalah antara dua sisi halal dan haram, bisa jadi ia lebih dekat kepada yang halal dan atau ia bisa lebih dekat kepada yang haram. Syubhat juga bisa tergantung pada seseorang, artinya ke-syubhat-an berlaku kepada orang tertentu tetapi tidak bagi orang lain. Maka dari itu, syubhat bisa disimpulkan sebagai sesuatu yang sangat subjektif.

Status syubhat dalam hadis Nabi Muhammad saw. di atas, bisa dikategorikan dalam tiga hal;

1. Kelompok yang memasukan syubhat sebagai perkara yang haram. Alasannya adalah sabda Nabi saw. "Barangsiapa yang menghindar dari yang samar maka dia telah menjaga agamanya dan kehormatannya. Dan barangsiapa yang terjatuh dalam perkara yang samar maka sangat tinggi sekali potensinya untuk terjerembab pada suatu yang terlarang".

2. Kelompok yang memasukan syubhat sebagai perkara yang halal. Alasannya adalah sabda Nabi saw. "seperti penggembala yang berada didekat jurang". Ini menunjukkan bahwa ia belum masuk pada status haram, seorang muslim hanya dituntut untuk berhati-hati saja agar tidak terjerumus pada suatu keharaman.

3. Kelompok yang mengatakan bahwa syubhat bukanlah halal dan bukan pula haram, alasan pernyataan ini adalah sabda Nabi saw. bahwa halal dan haram adalah suatu hal yang sudah jelas statusnya.

Kategorisasi syubhat dalam tiga kelompok ini merupakan eksistensi syubhat itu sendiri, ia tidak bisa ditetapkan sebagai sesuatu yang haram atau yang halal. Lebih tepat jika syubhat mempunyai status sendiri, syubhat adalah syubhat yang ketetapan pengerjaannya dikembalikan kepada pelaku. Demikian karena Nabi saw. yang bersabda bahwa "banyak sekali manusia yang tidak mengetahui hal-hal dengan status halal at au haram (syubhat)".

Nabi Muhmmad saw. sendiri mencontohkan bagaimana menyikapi suatu hal yang bersifat syubhat;

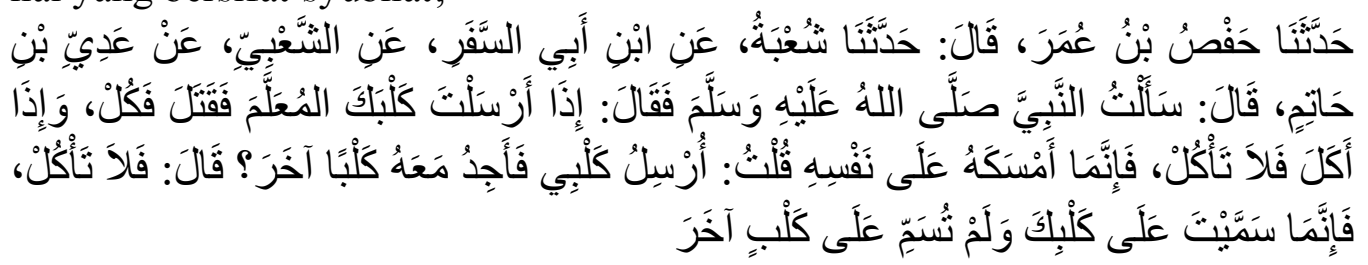

Artinya: 
'Adi bin Hātim bertanya kepada Nabi saw. prihal hewan buruan, Nabi saw. bersabda; jika kamu melepas anjing yang terlatih untuk memburu kemudian hewan buruan tersebut terbunuh, maka makanlah hewan buruan tersebut, dan jika anjing tersebut memakannya maka kamu janganlah ikut makan karena sesungguhnya anjing itu menangkap untuk dirinya sendiri. Saya ("Adi bin Hātim) berkata; saya melepas anjing saya dan pada saat itu saya melihat anjing lain. Nabi saw. bersabda; kamu jangan memakan hewan hasil buruan anjingmu, karena engkau membacakan basmalah kepada anjingmu tetapi tidak membacakan basmalah kepada anjing yang lain tersebut.

Kasus pemburuan yang diceritakan 'Adi bin Hātim adalah ketidakjelasan hasil hewan buruan, apakah hewan buruan tersebul hasil tangkapan anjingnya 'Adi bin Hātim yang ketika melepasnya untuk berburu hewan sudah dibacakan basmalah atau anjing lain yang pada saat itu ada bersamaan anjingnya 'Adi bin Hātim, sedangkan ia sendiri tidak menyaksikan anjing manakah yang berhasil menangkap hewan buruan tersebut.

\section{Dampak Halal, Haram, dan Syubhat bagi Manusia}

Rasulullah saw. dengan sabda halal, haram, dan syubhat ini memberitahukan kepada manusia bahwa ia mempunyai rambu-rambu kehidupan yang harus dipatuhi. Rambu-rambu ini sangat penting agar manusia dapat istiqamah atau kembali kepada asal di mana dulu ia diturunkan ke bumi. Halal, haram, dan syubhat adalah rambu-rambu agama yang harus diketahui. oleh seluruh umat Islam.

Halal, haram, dan syubhat melingkupi kehidupan manusia dari semua sisi kehidupannya, bukan terbatas pada makan dan minum yang harus diperhatikan, tetapi cara mendapatkan makanan dan minuman, bagaimana bertindak, bersikap bahkan berpikir harus senantiasa mempertimbangkan haluan rambu yang ada. Lingkup rambu dan aturan secara komprehensif terlihat dari penempatan Mukharrij al-Hadis terhadap hadis ini yang tidak hanya dalam bab al-Asyribah, tetapi ia juga menempatkan pada bab al-Imān dan al-Buyu'.

Syubhat merupakan wilayah atau jalur rawan. Karena itu, manusia dituntut untuk selalu waspada agar tidak terjebak hingga menyebabkan celaka pada dirinya. Syubhat merupakan jalur remang-remang yang memerlukan ketelitian dan kejelian. Usaha mengurai syubhat adalah usaha yang membutuhkan ijtihad yang sungguh-sungguh, upaya untuk menemukan dalil syariat, qiyās, istiṣhāa dan lain sebagainya untuk memastikan apakah termasuk suatu yang halal atau haram. ${ }^{43}$ Demikian rumitnya mengurai ke-syubhat-an, sehingga dibutuhkan kekuatan, kesehatan, dan ketepatan dalam berpikir, sebab tanpa dengan berpikir yang baik niscaya seseorang akan sulit terhidar dari celaka yang disebabkan perkara syubhat.

Kegagalan dalam menanggapi perihal syubhat, akan mudah tergelincir pada perkara yang haram, sedangkan pelaku haram mengakibatkan ancaman serius. Sungguh beruntung jika status syubhat tersebut mengarah pada suatu yang 
halal, tetapi jika suatu yang syubhat tersebut mengarah pada hal haram maka hal tersebut tentu menjadi suatu hal yang bahaya bagi diri manusia.

Dalam konsep agama Islam, perihal haram mengandung ancaman serius bagi pelakunya. Di antara ancamannya adalah:

1. Ibadah yang tertolak

Ketertolakan ibadah disabdakan Nabi saw. beliau bersabda;

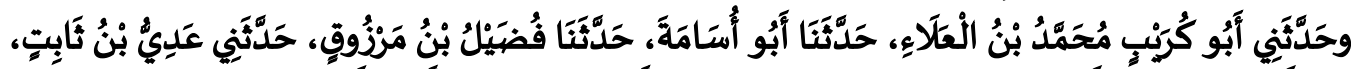

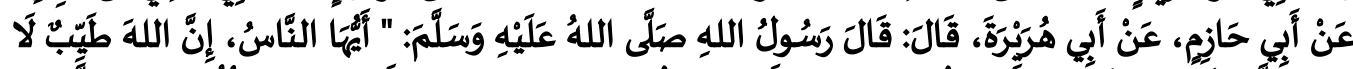

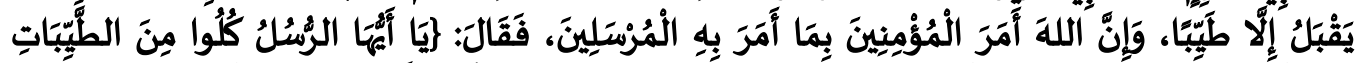

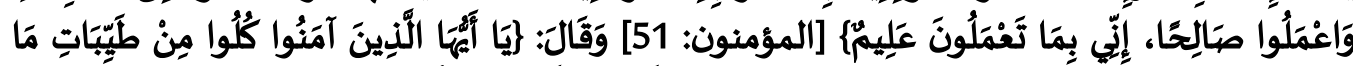

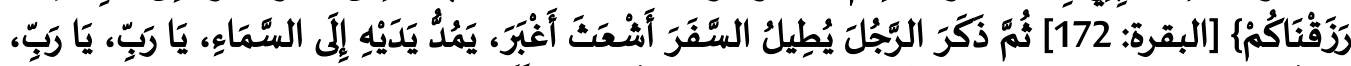

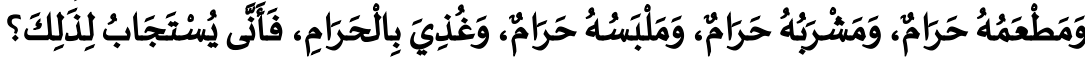

Artinya:

Abu Hurairah meriwayatkan bahwa Nabi Saw bersabda: Wahai manusia, Sesungguhnya Allah itu Maha Baik, Dia tidak menerima kecuali hal yang baik-baik. Sesungguhnya Allah memerintahkan orang beriman sebagaimana ia memerintahkan kepada para Rasul. Allah berfirman: "Wahai para rasul, makanlah dari sesuatu yang baik-baik, lakukanlah amalan yang saleh. Sesungguhnya Aku Maha Mengetahui terhadap apa yang kalian lakukan." Dan firmannya, "Wahai orang-orang yang beriman, makanlah hal yang baik-baik dari apa yang Kami rizkikan kepadamu." Kemudian Nabi menyebutkan seseorang yang jauh perjalanannya dan rambutnya yang acak-acakan berdoa dengan menengadahkan tangannya ke langit (sambil berkata), "Wahai Tuhan, wahai Tuhan." Sedangkan makanan, minuman dan pakaiannya adalah sesuatu yang haram. Maka bagaimana mungkin doanya terkabul?

2. Ancaman neraka

Hal ini juga berdasarkan sabda Nabi saw.

Artinya:

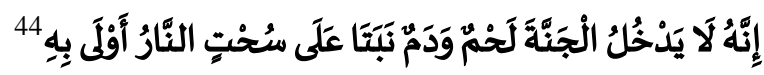

Sesungguhnya tidak masuk sorga daging dan darah yang tumbuh dari sesuatu yang haram, namun neraka lebih berhak untuknya

3. Membahayakan kesehatan

Banyak penelitian dilakukan tentang menkonsumsi makanan atau minuman yang diharamkan agama, berdampak buruk bagi kesehatan. Dengan hasil penelitian yang demikian, seakan-akan Allah swt. melarang manusia untuk tidak menkonsumsi barang-barang tertentu bukan hanya agar manusia tunduk terhadap segala perintahNya, tetapi demi kabaikan manusia itu sendiri. Maka dari, haruslah selalu disadari bahwa segala larangan Allah swt. kembalinya kepada diri manusia itu sendiri.

Dua dari tiga dampak di atas tentu sangat bersifat mistik, tetapi bagi orang yang beragama hal itulah yang menjadi titik sentral kehidupan. Sedangkan satu ancaman terhadap kesehatan, merupakan sebuah gaya hidup 
sehat yang perlu dilakukan dengan cara menghindari konsumsi yang dilarang agama.

Ancaman tersebut merupakan akibat atas perbuatan manusia yang tidak menghiraukan halal-haram sebuah sikap, tindakan, dan polanya. Terjadinya ancaman adalah akumulasi dari manusia itu sendiri, boleh terjadi dari ketidaktepatan berpikir selanjutnya menjadi perbuatan bahkan terus menjadi kebiasaan, namun sebelum hal itu terjadi, Nabi Muhammad saw. dalam salah satu redaksi yang berhubungan dengan hadis halal, haram dan syubhat ini menyebutkan al-qalb sebagai bagian organ tubuh manusia yang menjadi penentu atas keseluruhan jasad seseorang. Singkatnya, membaca sabda Nabi saw. tentang halal, haram dan syubhat ini ada hubungannya bahkan dapat menentukan keadaan al-qalb itu sendiri. Al-qalb ditentukan oleh ke-halal-an dan atau ke-haram-an setiap sesuatu yang diperbuat oleh pemiliknya.

Kata $a l-q a l b$ mengandung arti yang beragam. Jika mengikuti arti $a l-q a l b$ sebagai hati, sebuah organ dalam tubuh manusia, maka ia akan berfungsi sebagai alat penetralisir racun. Setelah racun sebuah makanan atau minuman yang masuk ke dalam tubuh manusia, maka ia akan terpancarkan ke seluruh jaringan sel tubuh manusia. Dengan demikian, al-qalb yang berarti hati menjadi inti penyebaran sari makanan dan minuman manusia. Maka jika makanan dan minuman tersebut diperoleh dengan cara, atau jenis makanan dan atau minuman itu sendiri haram, maka barang haramlah yang disebar dan diserap oleh seluruh jaringan sel tubuh.

Jika al-qalb diartikan sebagai jantung, maka ia akan berfungsi sebagai organ yang menyemburkan darah ke seluruh tubuh. Tanpa jantung, sirkulasi darah tidak akan berjalan, sedangkan darah adalah cairan yang membawa nutrisi yang diperlukan oleh setiap sel tubuh. Maka jantung pun berfungsi sebagai organ penting dan penentu kehidupan manusia.

Jika al-qalb diartikan sebagai akal dengan dimensi fisik, yakni otak, maka ia berfungsi sebagai organ yang memegang peran kunci untuk memerintah semua gerak yang ada dalam jasad manusia secara otomatis. Atau jika al-qalb diartikan sebagai akal dengan dimensi rohani, yakni organ yang bisa untuk berfikir, maka ia sangat dikatakan sebagai kunci nasib seluk beluk kehidupan pemiliknya. Jika cara berfikirnya keliru, maka niscaya tindakannya pun akan keliru.

Sabda Nabi saw. bahwa al-qalb penentu kebaikan dan keburukan manusia adalah rasional, karena kata al-qalb dalam semua makna yang dikandungnya memegang peran penting sebagai penentu kebaikan dan keburukan diri manusia. Dengan demikian, maka hati haruslah diperhatikan dengan cara memberikan asupan yang halal dan menghindarkan diri dari hal-hal haram karena hal tersebut hanya akan membuat al-qalb buruk dan rusak.

Berdasarkan hal-hal tersebut, sikap terhadap terhadap syubhat memerlukan kehati-hatian, sebab jika tidak, akan mudah terjerumus ke jurang keharaman. Walaupun status syubhat tidak semua tervonis sebagai sesuatu yang haram, tetapi antisipasi merupakan sebuah langkah bijak. Pada saat yang sama, jika semua yang masuk terhadap tubuh manusia, tindakan yang dilakukan serta cara 
yang digunakan adalah halal, maka ia akan mendapatkan keberkahan yang membawa kepada keselamatan, menyebabkan kebahagian dan keceriaan hidup.

\section{Kesimpulan}

Hadis tentang halal, haram, dan syubhat adalah hadis dalam kategori sahih. Halal dan haram dalam kehidupan umat Islam sudah jelas karena diuraikan dengan jelas dalam dalil naqli. Adapun perihal syubhat merupakan perkara yang membutuhkan kehati-hatian dalam menanggapinya, hingga Nabi Muhammad saw. sendiri sangat berhati-hati dalam menyikapinya. Hal tersebut terlihat dari riwayat sahabat 'Adi bin Hātim yang dilarang Nabi saw. untuk memakan hewan buruan dari hasil tangkapan anjingnya karena adanya anjing lain di samping anjing tersebut.

Halal dari segi pemaknaan mengandung makna kewajiban atau keharusan, sehingga sesuatu yang diketahui sebagai halal menjadikan seseorang harus memilihnya baik untuk dikonsumsi, dipergunakan, maupun dilakukan.

Haram bermakna melarang, mencabut, dan mencegah, sehingga sesuatu yang diketahui jelas keharamannya menjadikan seorang muslim untuk menghindarinya atau mencegah dirinya untuk menkonsumsi, mempergunakan, atau melakukannya.

Adapun syubhat adalah keadaan sesuatu yang belum jelas statusnya apakah sesuatu itu halal atau haram, sehingga jika seseorang menjumpai sesuatu yang tidak jelas kehalalan dan keharamannya, ia harus bersikap hati-hati, dan bentuk kehatihatian seseorang dengan menghindarinya.

Pengetahuan dan kemampuan dalam menentukan perkara halal, haram, dan syubhat mengantarkan pada kehidupan yang selamat dari keburukan dan kecelakaan, sehingga hidup menjadi tenang dan bahagia. 


\section{End Notes:}

${ }^{1}$ Lihat QS. Al-Balad/90: 8-10.

${ }^{2}$ Lihat QS. Al-Isra/17: 36.

${ }^{3}$ Zaenal Abidin, "Rahasia Hukum Islam dalam Ruang Peribadatan" Jurnal Adabiyah, Vol. 12 Nomor 2/2012, h. 23. dalam http://journal.uin-alauddin.ac.id/index.php/adabiyah/article/view/1715

${ }^{4}$ Lihat https://kbbi.kemdikbud.go.id/entri/syubhat (dikutip tanggal 23 Desember 2017)

${ }^{5}$ Muḥammad bin Ismā'îl al-Bukhāri, Saḥịh al-Bukhārì, Juz I (t.tt: Dār al-Ṭauq al-Najāh, 1422 H), h. 20.

${ }^{6}$ A.J. Weinsink, Miftāh Kunūz al-Sunnah, terj. Muhammad Fu'ạ̣ 'Abd al-Bāqìi (t.t: t.p, 1978), h 161

${ }^{7}$ Muḥammad bin Ismā'ìl al-Bukhāri, Saḥịh al-Bukhārī (Libanon; Dār al-Fikr, t.th), h. 33.

${ }^{8}$ Ibid, h. 486-487.

${ }^{9} \mathrm{Abu}$ al-Ḥusain Muslim bin al-Hajjāj al-Qusyairī al-Naisābūrì, Saḥịh Muslim (Beirut; Dār alFikr, 2003),h. 783-784.

${ }^{10} \mathrm{Abu}$ Dāwud Sulaimān bin al-Asy‘aṣ al-Sajastānī, Sunan Abī Dāwud, Juz II (Bairut: Dār alKutub al-'Ilmiah, 1996), h. 450.

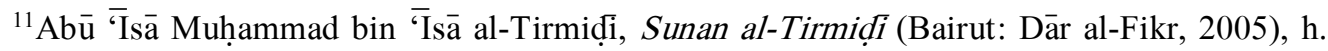
371.

${ }^{12} \mathrm{Abū}$ 'Abd al-Raḥmān Aḥmad bin Syu'aib bin 'Alì bin Sinān bin Baḥr al-Nasā'ì, Sunan alNasā'ī (Bairut: Dār al-Fikr, 2005), h. 1047.

${ }^{13}$ Ibid, h. 1271.

${ }^{14} \mathrm{Abu}$ 'Abd Allāh Muhammad bin Yazìd al-Quzwainì, Sunan Ibnu Mājah (t.t: Dār al-Fikr, 2003), h. 902.

${ }^{15} \mathrm{Abu}$ Muḥammad 'Abd Allāh bin 'Abd al-Raḥmān bin al-Faḍl bin Bahrām al-Dārimī, Sunan Al-Dārimì (Bairut: Dār Ibnu Hazm, 2002), h. 358.

${ }^{16} \mathrm{Abū} \mathrm{Nu}$ 'aim Aḥmad bin 'Abd Allāh bin Aḥmad bin Isḥāq bin Mihrān al-Aṣbahānī, Ma'rifah al-Ṣạābah, Juz V (Riyāẹ: Dār al-Waṭn, 1998), h. 2658.

${ }^{17}$ Sekarang, Himṣ adalah salah satu kota di Suriah.

${ }^{18} \mathrm{Abū} \mathrm{Nu}$ 'aim Aḥmad bin 'Abd Allāh bin Aḥmad bin Isḥāq bin Mihrān al-Aṣbahānī, Ma'rifah al-Ṣhạăbah, Juz V (Riyāẹ: Dār al-Waṭn, 1998), h. 2658.

${ }^{19}$ Aḥmad bin 'Ali bin Muhammad bin Aḥmad bin Hajr al-'Asqalānī, al-Isāăbah fì Tamyīz alSahābah, Juz VI (Bairut: Dār al-Kutub al-`Ilmiah, 1415 H), h. 346.

${ }^{20} \mathrm{Abū} N u$ 'aim Aḥmad bin 'Abd Allāh bin Aḥmad bin Ishāa bin Mihrān al-Aṣbahānī, Ma'rifah al-Sahāăbah, Juz V (Riyāụ: Dār al-Waṭn, 1998), h. 2658.

${ }^{21}$ Dalam delapan kitab hadis ini, adakalanya namanya hanya ditulis dengan al-Sya‘bi saja dan adakalanya hanya 'Āmir saja. Namun keduanya adalah orang yang sama. 
290.

${ }^{22}$ Ahmad Warson Munawwir, Kamus al-Munawwir (Surabaya: Pustaka Progresif 1997), h.

${ }^{23}$ Muḥammad bin Mukrim bin 'Ali al-Ifrììi, Lisān al- 'Arab, Juz XI (Bairut: Dār Ṣādir, 1414 H), h. 163.

${ }^{24}$ Ahmad Warson Munawwir, Kamus al-Munawwir (Surabaya: Pustaka Progresif 1997), h. 256.

${ }^{25}$ Muhammad bin Mukrim bin 'Ali al-Ifrịīi, Lisān al- 'Arab, Juz XII (Bairut: Dār Șādir, 1414 H), h. 122.

${ }^{26}$ Muḥammad bin Mukrim bin 'Ali al-Ifrìīi, Lisān al- 'Arab, Juz XII (Bairut: Dār Șādir, 1414 H), h. 122.

${ }^{27}$ Ahmad Warson Munawwir, Kamus al-Munawwir (Surabaya: Pustaka Progresif 1997), h. 125.

${ }^{28}$ Muhammad bin Mukrim bin 'Ali al-Ifriquì, Lisān al- 'Arab, Juz XIII (Bairut: Dār Ṣādir, 1414 H), h. 67. 691.

${ }^{29}$ Ahmad Warson Munawwir, Kamus al-Munawwir (Surabaya: Pustaka Progresif 1997), h.

${ }^{30}$ Muhammad bin Mukrim bin 'Ali al-Ifrīìi, Lisān al- 'Arab, Juz XIII (Bairut: Dār Ṣādir, 1414 H), h. 503.

${ }^{31}$ Ahmad Warson Munawwir, Kamus al-Munawwir (Surabaya: Pustaka Progresif 1997), h. 1145-1146.

${ }^{32}$ Muhammad bin Mukrim bin 'Ali al-Ifrììi, Lisān al- 'Arab, Juz I (Bairut: Dār Ṣādir, 1414 H), h. 685 .

${ }^{33}$ M. Quraish Shihab. Al-Qur'an \& Maknanya (Tangerang: Lentera Hati, 2013), h. 29.

${ }^{34}$ M. Quraish Shihab. Al-Qur'an \& Maknanya (Tangerang: Lentera Hati, 2013), h. 25.

${ }^{35}$ M. Quraish Shihab. Al-Qur'an \& Maknanya (Tangerang: Lentera Hati, 2013), h. 124.

${ }^{36}$ M. Quraish Shihab. Al-Qur'an \& Maknanya (Tangerang: Lentera Hati, 2013), h. 107.

${ }^{37}$ M. Quraish Shihab. Al-Qur'an \& Maknanya (Tangerang: Lentera Hati, 2013), h. 47.

${ }^{38}$ M. Quraish Shihab. Al-Qur'an \& Maknanya (Tangerang: Lentera Hati, 2013), h. 123.

${ }^{39}$ M. Quraish Shihab. Al-Qur'an \& Maknanya (Tangerang: Lentera Hati, 2013), h. 285.

${ }^{40}$ M. Quraish Shihab. Al-Qur'an \& Maknanya (Tangerang: Lentera Hati, 2013), h. 93.

${ }^{41}$ M. Quraish Shihab. Al-Qur'an \& Maknanya (Tangerang: Lentera Hati, 2013), h. 26.

${ }^{42}$ M. Quraish Shihab. Al-Qur'an \& Maknanya (Tangerang: Lentera Hati, 2013), h. 30.

${ }^{43} \mathrm{Abū}$ al-Ḥusain Muslim bin al-Ḥajjāj al-Qusyairì al-Naisābūrì, Sahịḥ Muslim (Beirut; Dār al-Fikr, 2003),h. 784.

${ }^{44}$ Muḥammad bin Ḥibbān bin Aḥmad bin Ḥibbān bin Mu'āz bin Ma‘bad al-Tamīmì, al-Iḥsān fi Taqrīb Saḥị̣ ibn Hibbān, Juz XII (Bairut: Muassasah al-Risālah, 1988), h. 378. 


\section{Daftar Pustaka}

\section{Al-Qur'an al-Karim}

Abidin, Zaenal "Rahasia Hukum Islam Dalam Ruang Peribadatan" Jurnal Adabiyah, Vol. 12 Nomor 2/2012 dalam http://journal.uinalauddin.ac.id/index.php/adabiyah/article/view/1715

al-Aṣbahānī, Abū Nu'aim Aḥmad bin 'Abd Allāh bin Aḥmad bin Isḥāq bin Mihrān. Ma 'rifah al-Saḥābah, Riyāụ: Dār al-Waṭn, 1998.

al-'Asqalānī, Ahmad bin 'Ali bin Muhammad bin Ahmad bin Hajr. al-Isāabah fi Tamyiz al-Sahābah, Bairut: Dār al-Kutub al-'Ilmiah, 1415 H.

al-Bukhāri, Muhammad bin Ismā'îl. Sahịịh al-Bukhārí, t.tt: Dār al-Ṭauq al-Najāh, $1422 \mathrm{H}$

al-Dārimì, Abū Muhammad 'Abd Allāh bin 'Abd al-Raḥmān bin al-Fạ̣l bin Bahrām. Sunan Al-Dàrimì, Bairut: Dār Ibnu Hazm, 2002.

al-Ifriqui, Muhammad bin Mukrim bin 'Ali, Lisān al-'Arab, Bairut: Dār Șādir, 1414 $\mathrm{H}$.

Munawwir, Ahmad Warson. Kamus al-Munawwir, Surabaya: Pustaka Progresif 1997

al-Naisābūrí, Abū al-Husain Muslim bin al-Hajjāj al-Qusyairì. Saḥiḥ Muslim, Beirut; Dār al-Fikr, 2003.

al-Nasā'ì, Abū 'Abd al-Raḥmān Aḥmad bin Syu'aib bin 'Ali bin Sinān bin Baḥr. Sunan al-Nasā', B̀, Bairut: Dār al-Fikr, 2005.

al-Quzwainī, Abū 'Abd Allāh Muhammad bin Yazìd. Sunan Ibnu Mājah, t.t: Dār alFikr, 2003.

al-Sajastānī, Abū Dāwud Sulaimān bin al-Asy'aṣ. Sunan Abī Dāwud, Bairut: Dār alKutub al-'Ilmiah, 1996.

Shihab, M. Quraish. Al-Qur'an \& Maknanya, Tangerang: Lentera Hati, 2013.

al-Tamīmi, Muhammad bin Hibbān bin Ahmad bin Hibbān bin Mu‘āz bin Ma‘bad. al-Ihsān fi Taqrīb Saḥịh ibn Hibbān, Bairut: Muassasah al-Risālah, 1988.

al-Tirmid̦̣i, Abū 'Isā Muḥammad bin 'Isā. Sunan al-Tirmiḍ̂i, Bairut: Dār al-Fikr, 2005.

Weinsink, A. J. Miftāh Kunūz al-Sunnah, terj. Muhammad Fu'ād 'Abd alBāqi t.t: t.p, 1978. 